\title{
INFLUENCE OF SULPIRIDE TREATMENT ON THE LEVEL OF PROLACTIN AND IMMUNOGLOBULINS IN THE PERIPHERAL BLOOD OF MARES DURING THE POSTPARTUM PERIOD
}

\author{
Anna Migdat ${ }^{1}$, Łukasz Migda ${ }^{2 *}$, Agata ZAGRAJCZUK ${ }^{1}$, Joanna KoCHAN ${ }^{1}$, \\ Agnieszka NOWAK ${ }^{1}$ and Adam OKÓLSKI ${ }^{1}$ \\ ${ }^{1}$ Institute of Veterinary Sciences, University of Agriculture in Kraków, \\ al. Mickiewicza 24-28, 30-059 Kraków, Poland; ${ }^{2}$ Department of Genetics and \\ Animal Breeding, University of Agriculture in Kraków, Kraków, Poland
}

(Received 15 January 2017; accepted 4 April 2017)

The aim of this study was to determine the effect of increased levels of prolactin (PRL) on the concentration of immunoglobulins in the blood, colostrum and milk of mares. The study was conducted on 12 mares of the Polish Pony breed (6 in the control and 6 in the experimental group). To induce hyperprolactinaemia in mares of the experimental group, $750 \mathrm{mg}$ sulpiride was administered orally once a day. The initial PRL concentration was $52.22 \pm 11.21 \mathrm{ng} / \mathrm{ml}$ in the control group and $49.39 \pm 10.12 \mathrm{ng} / \mathrm{ml}$ in the experimental group. In the subsequent days, the concentration of PRL dynamically changed. Statistical analysis showed highly significant differences $(\mathrm{P}<0.01)$ between the groups. The concentration of immunoglobulins in the blood plasma was at the same level during the experimental period $(32.97-29.08 \mathrm{mg} / \mathrm{ml}$ in the experimental group and $28.60-18.11 \mathrm{mg} / \mathrm{ml}$ in the control group). Statistical analysis showed highly significant differences between the groups in blood plasma immunoglobulin level $(\mathrm{P}<0.01)$. The highest immunoglobulin concentration was obtained within $12 \mathrm{~h}$ after parturition in the control and the experimental group $(23.49 \pm 2.12 \mathrm{mg} / \mathrm{ml}$ and $26.94 \pm 1.72 \mathrm{mg} / \mathrm{ml}$, respectively). The lowest values were obtained on day 12 after parturition in the experimental group $(10.15 \mathrm{mg} / \mathrm{ml} \pm 1.47 \mathrm{mg} / \mathrm{ml})$ and on day 7 after parturition in the control group $(14.30 \mathrm{mg} / \mathrm{ml} \pm 2.48 \mathrm{mg} / \mathrm{ml})$. In conclusion, this study did not provide evidence that the lactogenic hormone prolactin is involved in the transfer of immunoglobulins into the colostrum in horses. treatment

Key words: Mare, prolactin, immunoglobulin, postpartum period, sulpiride

There are complex relationships between the neuroendocrine and the immune system, which is expressed by their ability to interact through a network of hormones, neurotransmitters and cytokines. The pituitary gland can regulate the immune system via immunostimulatory hormones such as growth hormone $(\mathrm{GH})$

*Corresponding author; E-mail: lukasz.migdal@urk.edu.pl; Phone: 0048 (12) 662-4144; Fax: 0048 (12) 633-3307 
and prolactin (PRL), or through immunosuppressive hormones like adrenocorticotropic hormone (ACTH) (Jara et al., 2001). Plasma prolactin concentration in horses, as in most mammals, is stimulated by the long days of summer, and it is the lowest during the short days of winter (Nequin et al., 1993). In all vertebrates, PRL is a peptide consisting of 198 amino acids, acting as a hormone and having more than 300 different functions. The basic, well-known function of PRL is to stimulate the development of the alveolar part of the mammary gland and to induce and maintain lactogenesis. It has a luteotropic effect and stimulates the formation of progesterone in the corpus luteum. PRL participates in the stimulation of proliferation and differentiation processes of immune cells and angiogenesis (Straub et al., 2002; Vera-Lastra et al., 2002). It has been shown that PRL acts through specific membrane receptors (PRL-R) located in different tissues (Vera-Lastra et al., 2002). PRL-R participates in the transport of immunoglobulins from the blood plasma to the mammary gland. In cows, IgG1 was found to be specifically transported via transcytosis across the mammary epithelial cells during colostrogenesis (Baumrucker et al., 2010). PRL acts as a survival factor for immune system cells, protecting them from apoptosis. This occurs, e.g. in host reactions to stress, when the excessive secretion of glucocorticoids decreases the responsiveness of the immune system. Glucocorticoids are known to be able to induce apoptosis of immune cells (Davis, 1998). However, data on the interactions of prolactin with the immune system are not clear. The potential immunosuppressive effect of PRL was associated with a reduced cellular response in mice affected by sepsis as well as with their decreased survival (Oberbeck et al., 2003). Moreover, PRL is involved in the stimulation of antibody production by B cells, increasing the production of IgG and IgM presumably by enhancing the expression of receptors for IL-2 on plasma cells (Peeva et al., 2004). Hyperprolactinaemia (HPRL) is often accompanied by the presence of various autoantibodies, which confirms the stimulating effect of PRL on the production of immunoglobulins (Buskila et al., 1995).

PRL has been found to play a role in the pathogenesis of various autoimmune diseases, such as connective tissue diseases, including systemic lupus erythematosus (SLE), rheumatoid arthritis (RA) or Sjögren's syndrome (ParadaTurska et al., 2006). PRL affects the quality of milk. It has been found that the increased secretion of prolactin before delivery induces the synthesis and secretion of alpha-albumin in the mammary gland (Akers, 1985). PRL deficiency causes a deterioration in the quality of milk, and in particular reduces the secretion of significant complexes such as lactose, fat and protein (Barber et al., 1992). In mares, the increase of PRL secretion is associated with an elevation in the content of some milk constituents such as lactose, triglycerides and proteins (Forsyth et al., 1975). The hormone stimulates the production of lysozyme and reduces the high level of ceruloplasmin induced by inflammatory reactions (Yada et al., 2004). While prolactin is important for the development of the 
mammary gland and the onset of lactation, it is not necessary for the maintenance of milk production throughout lactation. Repeated bromocriptine treatment of lactating mares, although significantly reducing plasma prolactin concentrations, had no effect either on milk yield or on mammary gland size (Neuschaefer et al., 1991).

The active transport of immunoglobulins by enterocytes decreases about 15-16 $\mathrm{h}$ after delivery, and in foals this process can continue up to $38 \mathrm{~h}$ after delivery. The decrease of active transport can be explained by replacement of the intestinal epithelium full of receptors for the Fc fragment $(\mathrm{FcRn})$ by epithelium without this receptor (Jeffcott, 1974; Tizard, 2013). Taking into consideration the reports available in the literature, it seems to be confirmed that the level of immunoglobulins in the secretion of mammary glands increases during the first days of the foal's life. The aim of this study was to test the hypothesis that the level of prolactin can modulate the concentration of immunoglobulins in the blood and mammary gland secretions of mares.

\section{Materials and methods}

The experimental animals were reared in compliance with the Polish regulations for the humane care and use of animals in research.

\section{Animals}

The study was conducted on Polish Pony mares aged 4-19 years and kept at the Experimental Station of the Department of Reproduction and Animal Anatomy at the University of Agriculture in Kraków. Twelve mares were randomly divided into an experimental group $(\mathrm{n}=6)$ and a control group $(\mathrm{n}=6)$. All animals were clinically healthy before and during the experimental period. The experiment was conducted under a permission from the Local Ethics Committee. Parturitions took place from March to June. To induce hyperprolactinaemia mares, from the experimental group were administered $2 \mathrm{mg} / \mathrm{kg}$ body weight sulpiride (Sulpiride, Pliva) per os once a day. The experimental dose was estimated on the basis of available reports about hyperprolactinaemia (Besognet et al., 1997; Mari et al., 2009). The first dose was administered 2-3 hours after parturition, and the subsequent doses every day in the morning until the end of the experiment. The administration of sulpiride was started after parturition. This timing of sulpiride administration was selected in order not to induce lactation before parturition.

The dose of $2 \mathrm{mg} / \mathrm{kg}$ of body weight was chosen so that it should be significantly (three to six times) higher than that reported to induce hyperprolactinaemia successfully in other studies (Besognet el al., 1997; Mari et al., 2009). 


\section{Sample collections}

Peripheral blood plasma, colostrum and milk were collected before $12 \mathrm{~h}$ and $24 \mathrm{~h}$ post partum and then at 3, 5, 7, 10,12 and 15 days after delivery from all mares. Blood samples $(8 \mathrm{ml})$ were collected from the jugular vein into tubes containing heparin $(25 \mu \mathrm{l} / \mathrm{ml}$ blood Heparinum natricum, Polfa Warsaw). Plasma was obtained by the centrifugation of blood samples with $4500 \times \mathrm{g}$ for $5 \mathrm{~min}$ and stored at $-20{ }^{\circ} \mathrm{C}$ until further analysis. Mammary gland secretions $(4 \mathrm{ml})$ were collected into sterile plastic containers and stored at $-20{ }^{\circ} \mathrm{C}$ until analysis. All mares were milked by hand. Immunoglobulin and prolactin levels were measured in all blood, colostrum and milk samples collected between $12 \mathrm{~h}$ and 15 days after parturition.

\section{Measurement of plasma prolactin level}

Plasma prolactin concentration was measured by homologous doubleantibody radioimmunoassay with a highly purified equine hormone as standard for comparison and a specific antiserum raised against this standard. For iodination and preparation of the calibration curve ePRL (AFP8794B) was used. The assay validation and methodology were detailed previously (Donadeu and Ginther, 2002). Reagents were supplied by Dr. Parlow (NHPP, Torrance, USA). The intra- and interassay coefficients of variation $(\mathrm{CV})$ and the mean sensitivity for PRL were $13.6 \pm 1.05 \%, 12.21 \pm 1.6 \%$ and $1.56 \mathrm{ng} / \mathrm{ml}$, respectively. Analyses were performed in the laboratory of the Kielanowski Institute of Animal Physiology and Nutrition (Jabłonna, Poland).

\section{Determination of colostrum and plasma immunoglobulins}

The level of immunoglobulins was determined by a direct spectrophotometric method using a Folin-Ciocalteau reagent and a Metertech SP-8001 spectrophotometer at a wavelength of $750 \mathrm{~nm}$. First the level of total protein (TP) was determined by the method of Lowry et al. (1951), immunoglobulins (Ig) were precipitated using polyethylene glycol (25\%), and the level of protein (PIP) in the supernatant was determined. The immunoglobulin level was calculated by the formula Ig = TP - PIP (Ślebodzinski et al., 1982).

\section{Statistical analyses}

The SAS (v 9.0) program package (SAS Institute, Cary, NC, USA) was used for statistical analyses. A PROC MIXED procedure (ANOVA for repeated measurements) was performed to evaluate the effect of prolactin on plasma and colostrum Ig concentration. Tukey's test was used for multiple comparisons. 


\section{Results}

In samples collected before $12 \mathrm{~h}$ post partum PRL concentration was $49.39 \pm 10.12$ and $52.22 \pm 11.21 \mathrm{ng} / \mathrm{ml}$ in the experimental and the control group, respectively (Fig. 1). The highest average concentration of PRL was recorded on the first day after delivery. Between $12 \mathrm{~h}$ and day 5 post partum a rapid decrease in prolactin level was observed in both groups. The lowest concentration of PRL $(13.01 \mathrm{ng} / \mathrm{ml})$ was observed 5 days after parturition in the control group. On the subsequent days, PRL concentration was on a similar level in both groups. From day 3 post partum till the end of the experiment statistically significant differences $(P<0.01)$ in PRL concentration were found between the control and the experimental group. The profile of PRL changes did not differ between the groups. During the postpartum period the concentration of immunoglobulins in the blood plasma of mares from the experimental group was remained stable, with a slight increase from 30.09 to $32.97 \mathrm{mg} / \mathrm{ml}$ by day 5 post partum (Fig. 2). In the control group, an irregular decrease in immunoglobulin concentration was observed (from 28.60 to $18.11 \mathrm{mg} / \mathrm{ml}$ ) up to postpartum day 7 . In the subsequent few days, Ig concentration was at an equal level in the two groups. From postpartum day 3 till the end of the experiment statistically significant differences $(\mathrm{P}<0.001)$ were found between the control and the experimental groups in immunoglobulin level of the blood plasma. The level of immunoglobulins in the mammary gland secretions of mares in both groups varied in the postpartum period. The highest immunoglobulin content was found in samples taken before $12 \mathrm{~h}$ post partum in both the control $(23.49 \pm 2.12 \mathrm{mg} / \mathrm{ml})$ and the experimental $(26.94 \pm 1.72)$ group (Fig. 3$)$. The concentration of immunoglobulins decreased steadily from day 1 post partum. The lowest values were found at 12 days after parturition in the experimental group $(10.15 \mathrm{mg} / \mathrm{ml} \pm$ $1.47 \mathrm{mg} / \mathrm{ml}$ ). In the control group the concentrations of immunoglobulins decreased up to day 7 post partum $(14.30 \mathrm{mg} / \mathrm{ml} \pm 2.48 \mathrm{mg} / \mathrm{ml})$. On the subsequent days immunoglobulin concentration was at a similar level in the control group. There were no statistical differences between the control and the experimental group $(\mathrm{P}<0.0718)$ in immunoglobulin levels of the mammary gland secretions.

\section{Discussion}

Most studies on horses have shown that prolactin secretion is affected by season (Johnson, 1986; Thompson et al., 1986), feeding (Nadal et al., 1997; McManus and Fitzgerald, 2000), exercise or stress (Colborn et al., 1991; Thompson et al., 1994), endophyte-infected tall fescue consumption (McCann et al., 1992), sex and gonadal presence (Thompson et al., 1986), and treatment with dopamine antagonists (Thompson and DePew, 1997; Donadeu and Thompson, 2002). 


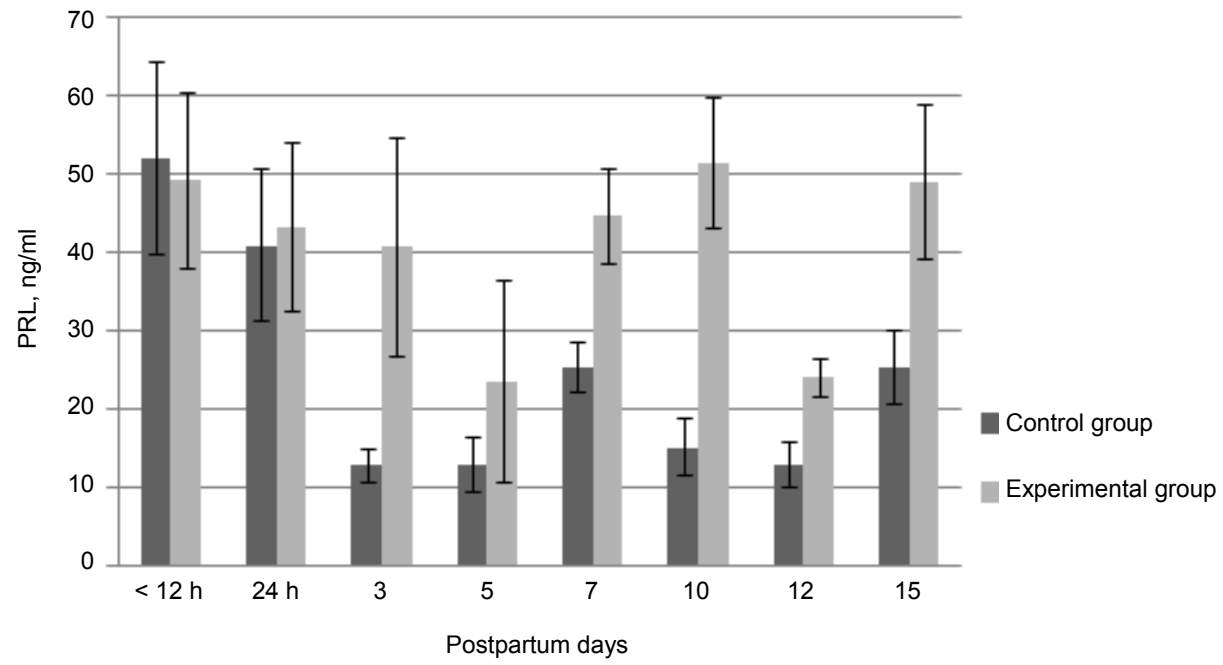

Fig. 1. Plasma concentrations of prolactin (PRL) during the postpartum period (mean $\pm \mathrm{SD}$ )

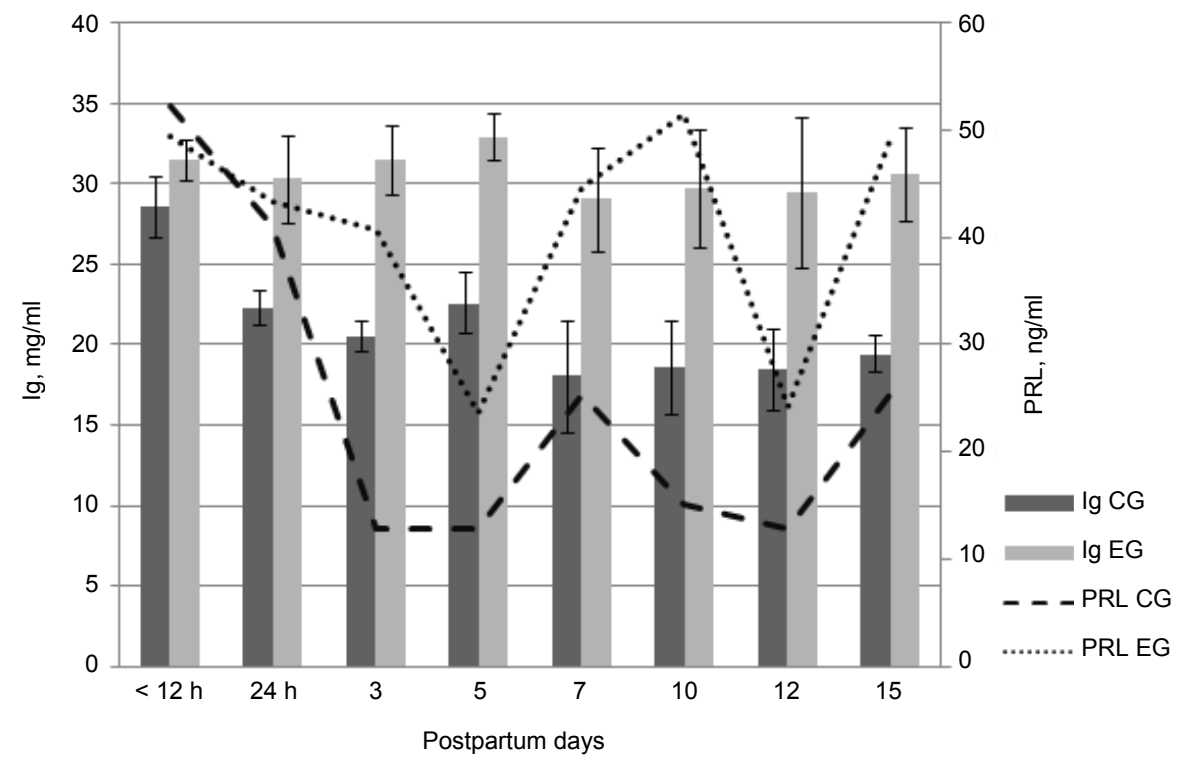

Fig. 2. Plasma concentration of immunoglobulins (Ig) and prolactin (PRL) (mean $\pm \mathrm{SD}$ ) in the control (CG) and the sulpiride-treated (EG) groups during the postpartum period 


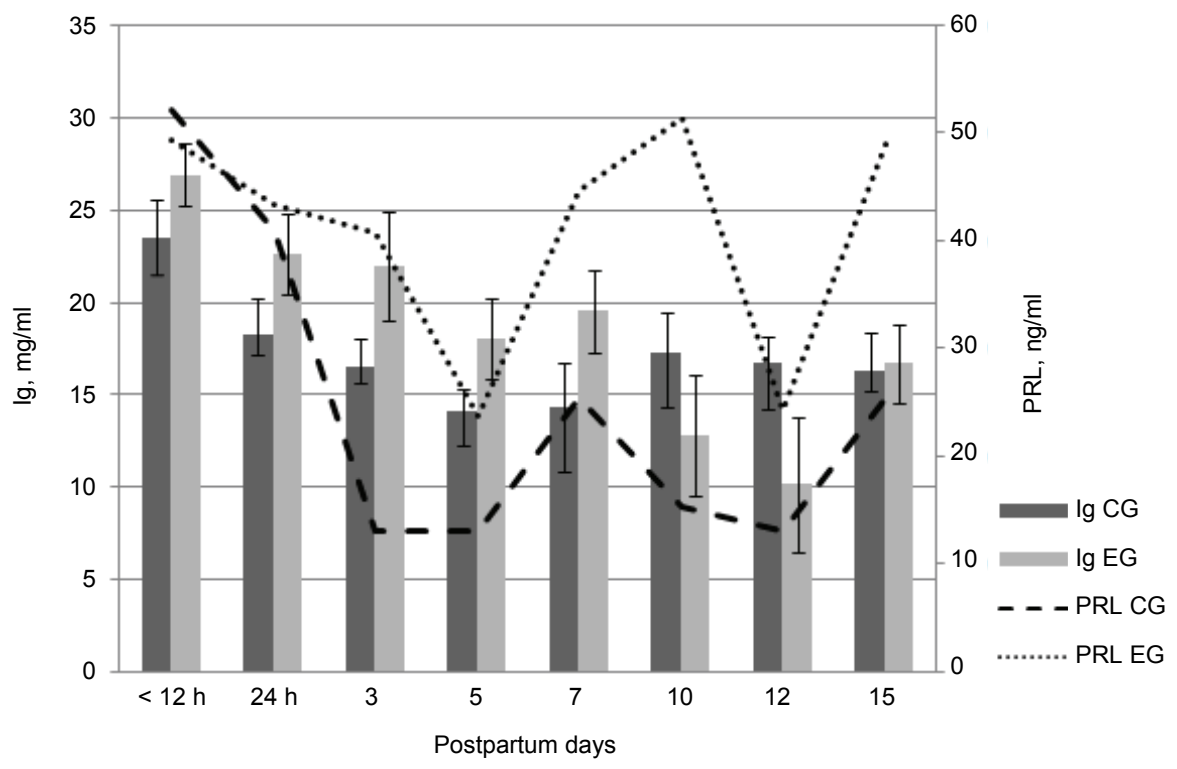

Fig. 3. Concentration of immunoglobulins (mean $\pm \mathrm{SD}$ ) in the mammary gland secretion of control (CG) and sulpiride-treated (EG) mares and plasma prolactin (PRL) concentration during the postpartum period

PRL concentration was found to be $70-100 \mathrm{ng} / \mathrm{ml}$ on the day of parturition and then it decreased to $4-20 \mathrm{ng} / \mathrm{ml}$ by day 10 post partum (Worthy et al., 1986). On the day of delivery, Korosue et al. (2013) found differences in prolactin concentrations between agalactic and control mares $(19.5$ and $67.0 \mathrm{ng} / \mathrm{ml}$, respectively). The results obtained for the pharmacologically non-stimulated groups were similar to those reported by Korosue et al. (2013). Studies conducted by Chavatte-Palmer et al. (2002) showed that the administration of sulpiride to sterile mares caused an increase in prolactin level from 27.7 to $289 \mathrm{ng} / \mathrm{ml}$ and induced lactation. In our experiment, a PRL concentration of $67.84 \mathrm{ng} / \mathrm{ml}$ was found, even though the sulpiride dose per kilogram of body weight was similar. This may result from the use of different breeds in the two experiments. In our experiment, mares of a primitive breed were used. Prolactin concentrations are reported to be higher during the summer than in winter (Thompson and Oberhaus, 2015). Compared to our study, results from experiments carried out during the summer (Chavatte-Palmer et al., 2002) have shown that sulpiride has less effect when PRL concentration is high, in contrast to individual predisposition (Gentry et al., 2002). In our study, a decrease in prolactin concentration up to day 10 post partum and a subsequent increase in the concentration of this hormone were observed. These observations support the findings of Worthy et al. (1987) and Heidler et al. (2003). The increase of prolactin concentration is apparently caused by suckling of the foals. Separation of mares and foals for several hours 
decreased plasma prolactin concentration in the mares. When the foals were again allowed to suck freely, plasma prolactin concentrations increased rapidly. The relationship between the suckling stimulus and prolactin secretion, however, appears to be less expressed in the horse (Wiest and Thompson, 1987) than in sheep (Knight et al., 1986) and pigs (Armstrong et al., 1998). Chavatte-Palmer et al. (2002) also investigated the quality of mammary gland secretions during pharmacologically induced lactation in non-pregnant and non-lactating mares. They obtained IgG values of 14-92 $\mathrm{mg} / \mathrm{ml}$ (one mare had $92 \mathrm{mg} / \mathrm{ml}$ and the others had $14-23 \mathrm{mg} / \mathrm{ml}$ ), while in our study the Ig concentrations varied between 2 and $66.1 \mathrm{mg} / \mathrm{ml}$. Generally, immunoglobulin $\mathrm{G}$ is the major immunoglobulin in equine serum, accounting for about $75 \%$ of all immunoglobulins (Tizard, 2013). Most studies are focused predominantly on IgG instead of total Ig because of their concentration in serum; this is due to the function of $\operatorname{IgG}$, most of which is absorbed and protect the newborn foal from systemic infections (Sedlinská et al., 2006). These results may be explained by major ontogenetic impacts on the quality of mammary gland secretions (Chavatte-Palmer et al., 2002), which was also observed in our experiment.

In this study, prolactin did not have an effect on the quality of colostrum, which is consistent with the results obtained by Foisnet et al. (2010) in sows. Studies on the effect of milk production on the colostrum and hormonal profile showed that sows with lower colostrum production are characterised by lower levels of PRL before delivery and between 10 and 20 hours post partum. However, there was no correlation between milk yield and $\operatorname{IgG}$ concentration (Foisnet et al., 2010). Thus, PRL concentration had no influence on colostral IgG level. According to some reports (Tallmadge et al., 2009), in foals sufficient IgM and IgG levels are attained by $2-3$ months post partum irrespective of colostrum ingestion. Moreover, Lewis et al. (2008) reported delayed endogenous production of $\mathrm{IgG}_{4-7}$ in foals. Sheoran et al. (2000) reported that $\mathrm{IgG}_{4-7}$ may not be detected in foals until 63 days of age. It is known that colostrum begins to accumulate in the udder a few weeks before delivery. Therefore, the lack of correlation may be explained by the specific immune system of horses. Foisnet et al. (2010) observed significantly higher levels of prolactin and cortisol in sows with induced farrowing than in sows with natural farrowing. The differences in the concentrations of these hormones did not affect the level of immunoglobulins in the colostrum (Foisnet et al., 2011). Similar results were obtained in goats (Castro et al., 2011). Goats with induced parturition had slightly decreased immunoglobulin levels in the colostrum with an increased level of prolactin in the blood plasma. It can also be concluded that an early high concentration of PRL is most likely responsible for the reduced transfer of IgG into the mammary secretions. Barrington et al. (1999) found that PRL decreases the expression of the bovine mammary IgG1 receptor at the onset of lactogenesis, resulting in decreased IgG1 level in the colostrum. They demonstrated that the increased level of prolactin in 
the blood plasma does not affect the concentration of immunoglobulins in the mammary gland secretions. The lack of correlation observed in our experiment between prolactin concentration and immunoglobulin level in the colostrum may also be due to late delivery of the agent stimulating the secretion of prolactin. Barrington et al. $(1999,2001)$ found a negative correlation between prolactin and IgG1 concentration as well as IgG1 receptor activity, while lactogenic activity was increased. It was shown that PRL increases the expression of polymeric receptors which translocate IgA to the colostrum (Foisnet et al., 2010). In our study we measured the concentration of total immunoglobulins. Different pathways controlling the transfer of immunoglobulins to the colostrum and dissimilar influence of PRL on those pathways may explain the lack of correlation between PRL and Ig concentration in our study. However, the lack of differences between the groups for the entire duration of the experiment suggests the validity of the hypothesis.

In conclusion, increased prolactin level significantly affects the concentration of immunoglobulins in the blood plasma, increasing their level.

\section{Acknowledgement}

This work was supported by the Polish Ministry of Science and Higher Education (funds for statutory activity, DS 3208).

\section{References}

Akers, R. M. (1985): Lactogenic hormones: binding sites, mammary growth, secretory cell differentiation, and milk biosynthesis in ruminants. J. Dairy Sci. 68, 501-519.

Armstrong, J. D., Kraeling, R. R. and Britt, J. H. (1998): Effects of naloxone or transient weaning on secretion of LH and prolactin in lactating sows J. Reprod. Fertil. 83, 301-308.

Barber, M. C., Clegg, R. A., Finley, E., Vernon, R. G. and Flint, D. J. (1992): The role of growth hormone, prolactin and insulin-like growth factors in the regulation of rat mammary gland and adipose tissue metabolism during lactation. J. Endocrinol. 135, 195-202.

Barrington, G. M., Besser, T. E., Gay, C. C., Davis, W. C., Reeves, J. J., McFadden, T. B. and Akers, R. M. (1999): Regulation of the immunoglobulin G1 receptor: effect of prolactin on in vivo expression of the bovine mammary immunoglobulin G1 receptor. J. Endocrinol. $163,25-31$.

Barrington, G. M., McFadden, T. B., Huyler, M. T. and Besser, T. E. (2001): Regulation of colostrogenesis in cattle. Livest. Prod. Sci. 70, 95-104.

Baumrucker, C. R., Burkett, A. M., Magliaro-Macrina, A. L. and Dechow, C. D. (2010): Colostrogenesis: mass transfer of immunoglobulin G1 into colostrum. J. Dairy Sci. 93, 3031-3038.

Besognet, B., Hansen, B. S. and Daels, P. F. (1997): Induction of reproductive function in anestrous mares using a dopamine antagonist. Theriogenology 15, 467-480.

Buskila, D., Berezin, M., Gur, H., Lin, H. C., Alosachie, I., Terryberry, J. W., Barka, N., Shen, B., Peter, J. B. and Shoenfeld, Y. (1995): Autoantibody profile in the sera of women with hyperprolactinemia. J. Autoimmun. 8, 415-424. 
Castro, N., Capote, J., Batista, M., Bruckmaier, R. M. and Argüello, A. (2011): Effects of induced parturition in goats on immunoglobulin $\mathrm{G}$ and chitotriosidase activity in colostrum and plasma and on plasma concentrations of prolactin. Domest. Anim. Endocrinol. 40, 192-196.

Chavatte-Palmer, P., Arnaud, G., Duvaux-Ponter, C., Brosse, L., Bougel, S., Daels, P., Guillaume, D., Clément, F. and Palmer, E. (2002): Quantitative and qualitative assessment of milk production after pharmaceutical induction of lactation in the mare. J. Vet. Intern. Med. 16, $472-477$.

Colborn, D. R., Thompson, D. L. Jr., Roth, T. L., Capehart, J. S. and White, K. L. (1991): Responses of cortisol and prolactin to sexual excitement and stress in stallions and geldings. J. Anim. Sci. 69, 2556-2562.

Davis, S. L. (1998): Environmental modulation of the immune system via the endocrine system. Domest. Anim. Endocrinol. 15, 283-289.

Donadeu, F. X. and Ginther, O. J. (2002): Follicular waves and circulating concentrations of gonadotrophins, inhibin and oestradiol during the anovulatory season in mares. Reproduction 124, 875-885.

Donadeu, F. X. and Thompson, D. L. Jr. (2002): Administration of sulpiride to anovulatory mares in winter: effects on prolactin and gonadotropin concentrations, ovarian activity, ovulation and hair shedding. Theriogenology 15, 963-976.

Foisnet, A., Farmer, C., David, C. and Quesnel, H. (2010): Relationships between colostrum production by primiparous sows and sow physiology around parturition. J. Anim. Sci. 88, $1672-1683$.

Foisnet, A., Farmer, C., David, C. and Quesnel, H. (2011): Farrowing induction induces transient alterations in prolactin concentrations and colostrum composition in primiparous sows. J. Anim. Sci. 89, 3048-3059.

Forsyth, I. A., Rossdale, P. D. and Thomas, C. R. (1975): Studies on milk composition and lactogenic hormones in the mare. J. Reprod. Fertil. Suppl. 23, 631-635.

Gentry, L. R., Thompson, Jr. D. L., Gentry, G. T. Jr., Davis, K. A., Godke, R. A. and Cartmill, J. A. (2002): The relationship between body condition, leptin, and reproductive and hormonal characteristics of mares during the seasonal anovulatory period. J. Anim. Sci. 80, 2695-2703.

Heidler, B., Parvizi, N., Sauerwein, H., Bruckmaier, R. M., Heintges, U., Aurich, J. E. and Aurich, C. (2003): Effects of lactation on metabolic and reproductive hormones in Lipizzaner mares. Domest. Anim. Endocrinol. 25, 47-59.

Jeffcott, L. B. (1974): Some practical aspects of the transfer of passive immunity to newborn foals. Equine Vet. J. 6, 109-115.

Jara, L. J., Vera-Lastra, O., Miranda, J. M., Alcala, M. and Alvarez-Nemegyei, J. (2001): Prolactin in human systemic lupus erythematosus. Lupus 10, 748-756.

Johnson, A. L. (1986): Serum concentrations of prolactin, thyroxine and triiodothyronine relative to season and the estrus cycle in the mare. J. Anim. Sci. 62, 1012-1020.

Knight, P. G., Howles, C. M. and Cunningham, F. J. (1986): Evidence that opioid peptides and dopamine participate in the suckling-induced release of prolactin in the ewe. Neuroendocrinology 44, 29-35.

Korosue, K., Murase, H., Sato, F., Ishimaru, M., Watanabe, G., Harada, T., Taya, K. and Nambo, Y. (2013): Changes in serum concentrations of prolactin, progestagens, and estradiol-17 $\beta$ and biochemical parameters during peripartum in an agalactic mare. J. Equine Vet. Sci. 33, 279-286.

Lewis, M. J., Wagner, B. and Woof, J. M. (2008): The different effector function capabilities of the seven equine IgG subclasses have implications for vaccine strategies. Mol. Immunol. 45, $818-827$.

Lowry, O. H., Rosebrough, N. J., Farr, A. L. and Randall, R. J. (1951): Protein measurement with the Folin phenol reagent. J. Biol. Chem. 193, 265. 
Mari, G., Morganti, M., Merlo, B., Castagnetti, C., Parmeggiani, F., Govoni, N., Galeati G. and Tamanini, C. (2009): Administration of sulpiride or domperidone for advancing the first ovulation in deep anestrous mares. Theriogenology 71, 959-965.

McCann, J. S., Caudle, A. B., Thompson, F. N., Stuedemann, J. A., Heusner, G. L. and Thompson, D. L. Jr. (1992): Influence of endophyte-infected tall fescue on serum prolactin and progesterone in gravid mares. J. Anim. Sci. 70, 217-223.

McManus, C. J. and Fitzgerald, B. P. (2000): Effects of a single day of feed restriction on changes in serum leptin, gonadotropins, prolactin and metabolites in aged and young mares. Domest. Anim. Endocrinol. 19, 1-13.

Nadal, M. R., Thompson, D. L. Jr. and Kincaid, L. A. (1997): Effect of feeding and feed deprivation on plasma concentrations of prolactin, insulin, growth hormone, and metabolites in horses. J. Anim. Sci. 75, 736-744.

Nequin, L. G., King, S. S., Johnson, A. L., Gow, G. M. and Ferreira-Dias, G. M. (1993): Prolactin may play a role in stimulating the equine ovary during the spring transition. J. Equine Vet. Sci. 13, 631-635.

Neuschaefer, A., Bracher, V. and Allen, W. R. (1991): Prolactin secretion in lactating mares before and after treatment with bromocriptine. J. Reprod. Fertil. Suppl. 44, 551-559.

Oberbeck, R., Schmitz, D., Wilsenack, K., Schuler, M., Biskup, C., Schedlowski, M., Nast-Kolb, D. and Exton, M. S. (2003): Prolactin modulates survival and cellular immune functions in septic mice. J. Surg. Res. 113, 248-256.

Parada-Turska, J., Targońska-Stępniak, B. and Majdan, M. (2006): Prolactin in connective tissue diseases [in Polish, with English abstract]. Postepy Hig. Med. Dosw. 60, 278-285.

Peeva, E., Venkatesh, J., Michael, D. and Diamond, B. (2004): Prolactin as a modulator of B cell function: implications for SLE. Biomed. Pharmacother. 58, 310-319.

Sedlinská, S., Krejcí, J., Vyskočil, M. and Kudláčková, H. (2006): Postnatal development of blood serum concentrations of immunoglobulin IgG, IgA and IgM isotypes in suckling foals. Acta Vet. Brno 75, 175-182.

Sheoran, A. S., Timoney, J. F., Holmes, M. A., Karzenski, S. S. and Crisman, M. V. (2000): Immunoglobulin isotypes in sera and nasal mucosal secretions and their neonatal transfer and distribution in horses. Am. J. Vet. Res. 61, 1099-1105.

Straub, R. H., Georgi, J., Helmke, K., Vaith, P. and Lang, B. (2002): In polymyalgia rheumatica serum prolactin is positively correlated with the number of typical symptoms but not with typical inflammatory markers. Rheumatology 41, 423-429.

Ślebodziński, A., Brzezińska-Ślebodzińska, E., Lipczak, W. and Rosa, E. (1982): A simple clinical test to determine the level of total immunoglobulin and protein in blood serum from newborn livestock [in Polish]. Med. Wet. 8-9, 442-446.

Tallmadge, R. I., McLaughlin, K., Secor, E., Ruano, D., Matychak, M. B. and Flaminio, M. J. (2009): Expression of essential B cell genes and immunoglobulin isotypes suggests active development and gene recombination during equine gestation. Dev. Comp. Immunol. 33, 1027-1038.

Thompson, D. L. Jr. and DePew, C. L. (1997): Prolactin, gonadotropin, and hair shedding responses to daily sulpiride administration in geldings in winter. J. Anim. Sci. 75, 1087-1091.

Thompson, D. L. Jr. and Oberhaus, E. L. (2015): Prolactin in the horse: historical perspective, actions and reactions, and its role in reproduction. J. Equine Vet. Sci. 35, 343-353.

Thompson, D. L. Jr., DePew, C. L., Ortiz, A., Sticker, L. S. and Rahmanian, M. S. (1994): Growth hormone and prolactin concentrations in plasma of horses: Sex differences and the effects of acute exercise and administration of growth hormone releasing hormone. J. Anim. Sci. 72, 2911-2918.

Thompson, D. L. Jr., Johnson, L., St. George, R. L. and Garza, F. Jr. (1986): Concentrations of prolactin, luteinizing hormone and follicle stimulating hormone in pituitary and serum of horses: Effect of sex, season and reproductive state. J. Anim. Sci. 63, 854-860.

Tizard, I. R. (2013): Veterinary Immunology. 9th edition. Elsevier/Saunders, St. Louis, MO. 
Vera-Lastra, O., Jara, L. J. and Espinoza, L. R. (2002): Prolactin and autoimmunity. Autoimmunity Rev. 1, 360-364.

Wiest, J. J. and Thompson, D. L. (1987): Plasma prolactin, LH and FSH concentrations after suckling in post-partum mares. J. Reprod. Fertil. Suppl. 35, 731-732.

Worthy, K., Colquhoun, K., Escreet, R., Dunlop, M., Renton, J. P. and Douglas, T. A. (1987): Plasma prolactin concentrations in non-pregnant mares at different times of the year and in relation to events in the cycle. J. Reprod. Fertil. Suppl. 35, 269-276.

Worthy, K., Escreet, R., Renton, J. P., Eckersall, P. D., Douglas, T. A. and Flint, D. J. (1986): Plasma prolactin concentration and cyclic activity in pony mares during parturition and early lactation. J. Reprod. Fertil. 77, 569-574.

Yada, T., Muto, K., Azuma, T. and Ikuta, K. (2004): Effects of prolactin and growth hormone on plasma levels of lysozyme and ceruloplasmin in rainbow trout. Comp. Biochem. Phys. C 139, 57-63. 